\title{
Corrigendum to "Adipose-Derived Mesenchymal Stem Cells in the Regeneration of Vocal Folds: A Study on a Chronic Vocal Fold Scar"
}

\author{
Valerie Angelou, ${ }^{1}$ Vassiliki Kalodimou, ${ }^{2}$ Irini Messini, ${ }^{3}$ Nikolaos Psychalakis, ${ }^{4}$ \\ Eleftheria Karampela, ${ }^{4}$ and Apostolos Papalois ${ }^{4}$ \\ ${ }^{1}$ Phoniatrics and Applied Otorhinolaryngology Center, Amalias Avenue 42, 10542 Athens, Greece \\ ${ }^{2}$ Department of Flow Cytometry-Research \& Regenerative Medicine, IASO Maternity Hospital, Kifissias Avenue 37-39, \\ Maroussi, 15123 Athens, Greece \\ ${ }^{3}$ Pathology Department, IASO Maternity Hospital, Kifissias Avenue 37-39, Maroussi, 15123 Athens, Greece \\ ${ }^{4}$ Experimental \& Research Center, ELPEN, 95 Marathonos Avenue, Pikermi, Attica, 19009 Athens, Greece
}

Correspondence should be addressed to Valerie Angelou; valerie_angelou@hotmail.com

Received 24 June 2016; Accepted 4 July 2016

Copyright (c) 2016 Valerie Angelou et al. This is an open access article distributed under the Creative Commons Attribution License, which permits unrestricted use, distribution, and reproduction in any medium, provided the original work is properly cited.

In the article titled "Adipose-Derived Mesenchymal Stem Cells in the Regeneration of Vocal Folds: A Study on a Chronic Vocal Fold Scar" [1], the authors' first and last names were reversed. The corrected authors' list is shown above.

\section{References}

[1] A. Valerie, K. Vassiliki, M. Irini, P. Nikolaos, E. Karampela, and P. Apostolos, "Adipose-derived mesenchymal stem cells in the regeneration of vocal folds: a study on a chronic vocal fold scar," Stem Cells International, vol. 2016, Article ID 9010279, 12 pages, 2016. 

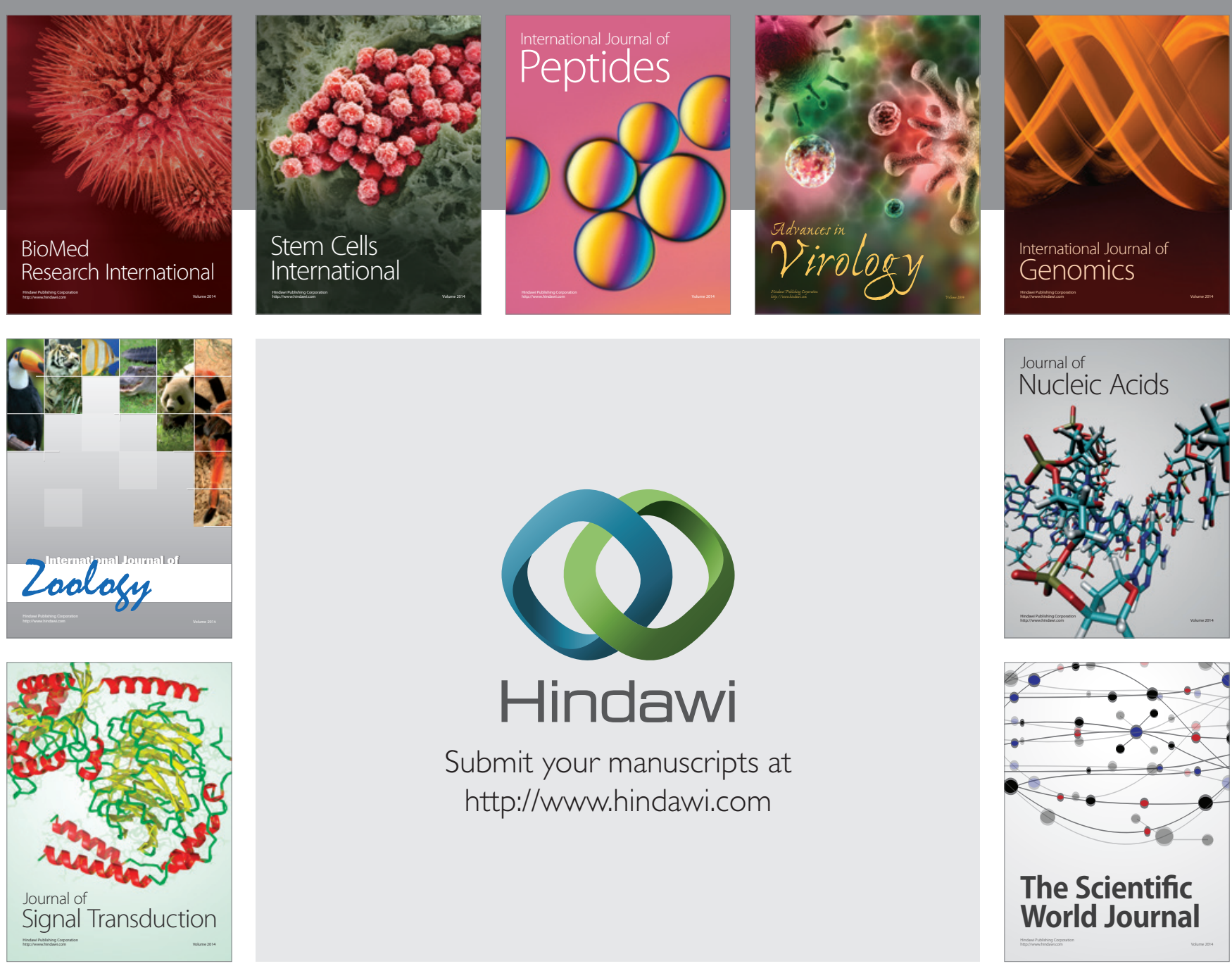

Submit your manuscripts at

http://www.hindawi.com
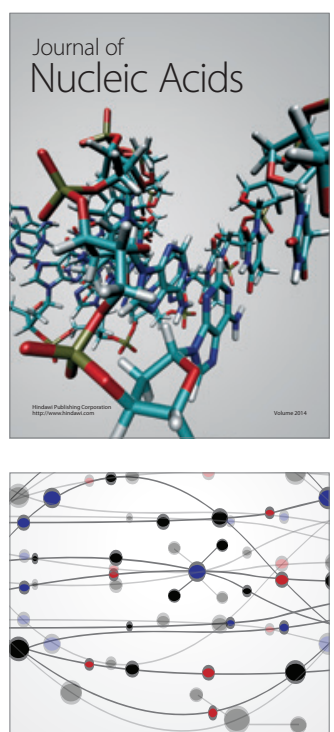

The Scientific World Journal
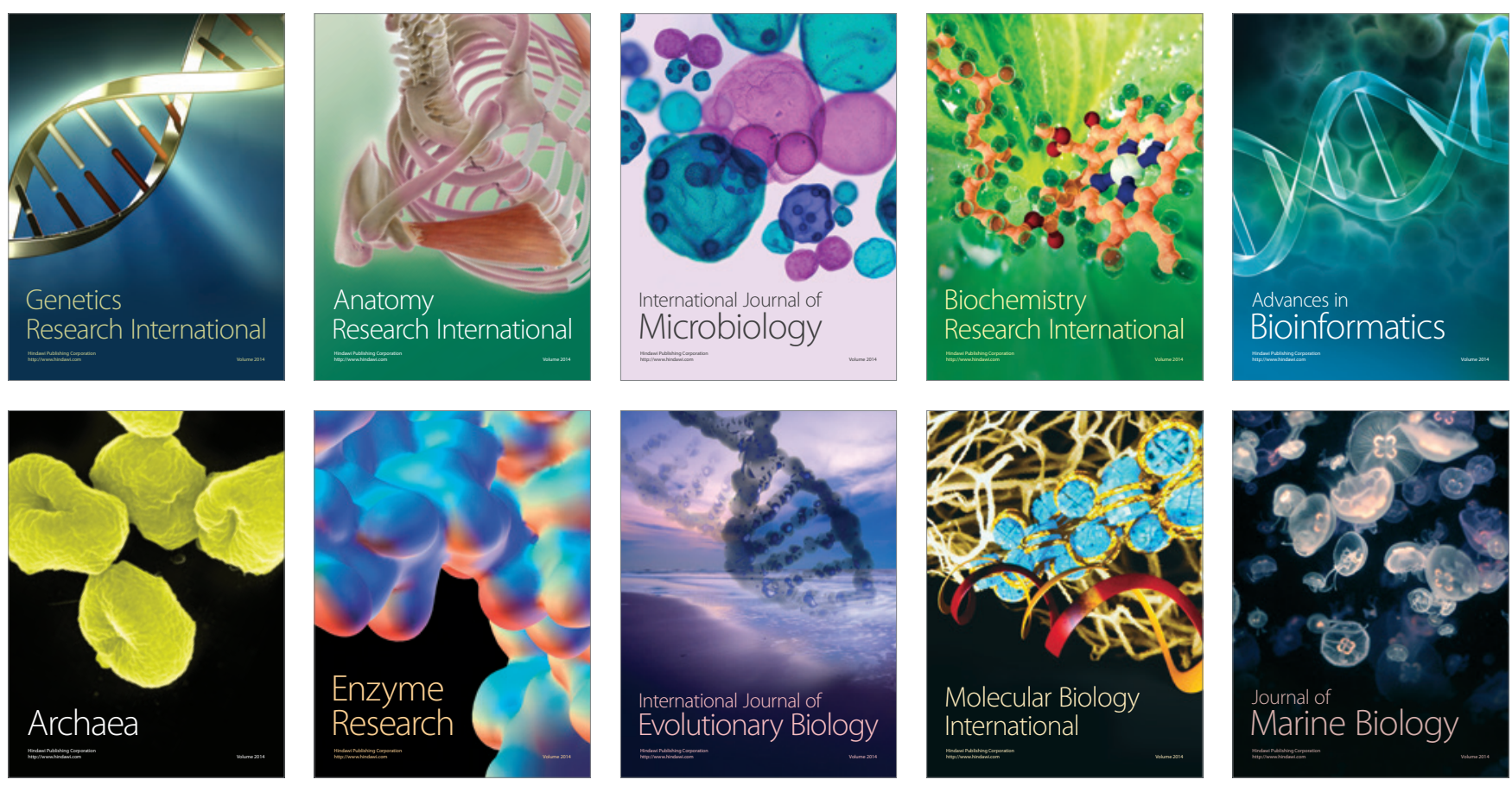